\title{
Identity and National Belonging in Ansaruallah's Political Rhetoric: A Transitivity Analysis
}

\author{
Gibreel Sadeq Alaghbary ${ }^{1}$ \\ ${ }^{1}$ Associate professor of Sylistics, Center for Languages and Translation, Taiz University, Taiz, Yemen; Qassim \\ University, Qassim, KSA \\ Correspondece: Gibreel Sadeq Alaghbary, Qassim University, P. O. Box 574, Alkhalidiyah, Almethnab 51931, \\ Qassim, KSA. Tel: 966-163-695-987. E-mail: gibreelsadeq@yahoo.com
}

\author{
Received: February 13, 2017 Accepted: March 9, 2017 Online Published: July 16, 2017 \\ doi:10.5539/ijel.v7n4p247 URL: http://doi.org/10.5539/ijel.v7n4p247
}

\begin{abstract}
The present study concerns the application of the transitivity model as an analytical tool in the investigation of ideology in political rhetoric. Specifically, the paper examines the issues of national belonging and the construction of identity in Ansaruallah's proposals to the National Dialog Conference in 2013. The data for the study is constituted, for considerations of thematic relevance, by the Sa'ada Issue part of the proposals. The objective of the analysis is to find out in what terms Ansarullah's identity is constructed, how the nation is promoted as a value in Ansaruallah's political rhetoric, and how important national belonging is in Ansaruallah's construction of their social identity. In order to address these concerns, the paper analyzes the nominal and verbal constructions in the proposals using the linguistic framework of the transitivity model (Simpson, 1988). Findings from the analysis reveal that Ansaruallah construct themselves as an oppressed group whose members are bound by religion and oppression, rather than by a nationalist bond. Indeed, Ansaruallah distance themselves from Yemen, fellow Yemenis, the national government and from national institutions, and instead express emotional attachment to Sa'ada, which is construed as the homeland, and solidarity with Ansaruallah militants and Sa'ada residents, who are construed as the co-nationals of the homeland.
\end{abstract}

Keywords: Ansaruallah, identity, national belonging, NDC, transitivity analysis, Yemen

\section{Introduction}

Once confined to the northern peripheral highlands, the Houthis (or Ansaruallah as they prefer to be addressed) control much of Yemen's north today. Once an educational center of Zaydi revivalism, Ansaruallah are a heavily armed militia today. Once an outlawed rebel group, Ansaruallah are more or less the de facto governing authority in Yemen (or at least in north Yemen) today. And once marginalized, the group is now marginalizing. It all started in 1986 when a group of religious scholars in the northwest Yemeni province of Sa'ada established a Zaydi revivalist movement known "Ittihad al-Shabab" (Union of the Youth). It was a movement of religious education that aimed mainly at the revival of beliefs and cultural heritage of the Zaydi sect in Yemen

The Unification of North and South Yemen in 1990 brought with it a constitution that guaranteed partisan pluralism in the country. Capitalizing on the new legislation, the Ittihad al-Shabab movement morphed into a political party that was called Hizul Haq (Party of Truth). The party contested the 1993 and 1997 parliamentary elections and won two seats each one of which went to Hussein the son of Baddreddin al-Houthi. In 1997, Baddreddin al-Houthi and his followers defected from the party and started the more radical "Muntada al-Shabab al-Mu'min" (Assembly of the Believing Youth) that was later transformed into the more organized "Tanzim Al-Shabab al-Mumin" (Lux, 2009). Hussein al-Houthi took over in 2001 and split off from the Tanzim and started a more traditional, less liberal group whose aim was the assertion of their Zaydi identity. The new group considered Baddreddin al-Houthi its spiritual leader, revered the teachings (in the form of Malazim or booklets) of his son Hussein al-Houthi, and was successively led thereof by members of the Houthi family. Therefore, the group has come to be popularly known as "al-Houthi Group" and followers of the movements as the Houthis.

Opposition to the US invasion of Iraq in 2003 and the growing assertiveness of the Shiite identity in the region made the movement even more assertive. It adopted anti-American rhetoric and chanted anti-American slogans. Wary of losing the support of its American ally, the Yemeni government launched a police operation that ended in the killing of Hussein al-Houthi and the arrest of his father. Abdulmalik al-Houthi, Hussein's brother, took 
over and the movement became increasingly confrontational with the state. He transformed the movement into "an insurgent force ideologically unified by a deep reverence for the martyr Husayn al-Huthi" (Winter, 2013, p. 7). Between 2004 and 2010, the Houthi group engaged in six sporadic wars with the government, the last of which involved the Saudi military as well. And it was during this period that the group rebranded themselves as Ansaruallah, even though "the media continued and continues" to refer to the group as the Houthis (Winter, 2013, p. 7).

Although a cease-fire was reached in February 2010, Government rhetoric continued to escalate, and so did Ansaruallah rhetoric. The government accused the movement of receiving aid from Iran and of conspiring to overturn "democracy" and reinstate the clerical Shiite imamate that had ruled Yemen before its 1962 revolution. In response, Ansaruallah's rhetoric was dominated by opposition to "outside incursions into their affairs", either by local actors (e.g., the Yemeni state), regional actors (e.g., Saudi Arabia) or by international actors (e.g., the USA) (IslamopediaOnline, 2012, p. 11).

In 2011, Ansarullah joined the nationwide anti-regime protest movement demanding the ouster of Saleh and the redress of economic and social grievances. In the height of the popular uprising, Saleh's appointed governor in Sa'da withdrew, leaving the city out of central government radar. A new governor, alley of Ansarullah, was elected by an assembly of local influential leaders. The province of Sa'da was under the undisputed control of the movement.

Control of Sa'da and the ability to expand, ideologically and militarily, beyond the province made Ansarullah a key player in the National Dialog Conference (hereafter NDC) started in February 2013 and concluded in January 2014. Initially, the movement rejected the GCC-brokered agreement and by implication participation in the NDC. Later, the movement changed its position and joined the NDC. They sent delegates and made their own proposals to solving the major issues facing the state, including the $\mathrm{Sa}$ 'da issue.

Ansaruallah's proposals have been published by the Political Council of Ansarullah in book form. The book addresses four national issues: the Sa'da issue, the southern issue, building the state, and good governance. The present paper investigates traditional markers of identity and belonging in Ansaruallah's routinic behavior, and, more significantly, applies the transitivity model to the first part of the book in order to investigate these issues in the political rhetoric of a movement that is widely, albeit without conclusive evidence, accused of subservience to a foreign agenda, namely, to that of Iran.

\subsection{Identity}

Even though the word "identity" enjoys a wide circulation across a wide spectrum of disciplines, including social psychology and political science, the concept remains "slippery... and not only contested but contestable" (Anthias, 2008, p. 7). Dictionary entries, for example, have at their core a conceptualization of the term as denoting the set of qualities or characteristics that make a particular person or group different from others. While this serves well as working definition, it does not do justice to the rich connotations of the term.

Literature on identity has produced a wide range of more remarkable formulations of the concept. Hogg and Abrams (1998, p. 2) define identity as "people's concepts of who they are, of what sort of people they are, and how they relate to others". For Deng $(1995$, p. 1), identity is used to describe "the way individuals and groups define themselves and are defined by others on the basis of race, ethnicity, religion, language, and culture". And Jenkins (1996, p. 4) uses the term to refer to the "ways in which individuals and collectivities are distinguished in their social relations with other individuals and collectivities". Central to all these definitions is the concept of the identification of selfhood in opposition to/in relation to the other.

Fearon (1999) enriches the definition even further. He argues that that current usage of the term is more complicated. The present intension of the word in the social sciences, Fearon continues, is associated with two linked senses, the personal and the social. In its personal sense, an identity is "some distinguishing characteristic (or characteristics) that a person takes a special pride in or views as socially consequential but more-or-less unchangeable"; in its social sense, on the other hand, identity refers to "a social category, a set of persons marked by a label and distinguished by rules deciding membership and (alleged) characteristic features or attributes" ( $\mathrm{p}$. 2). The two senses are not diverse; indeed, the richness of the term derives from the linkage of the two senses.

An individual's personal identity is a composite of physical attributes and moral beliefs that define their way of life. Fearon (1999) stipulates a number of conditions in order for these attributes to define personal identity,

Personal identity is a set of attributes, beliefs, desires, or principles of action that a person thinks distinguish her in socially relevant ways and that (a) the person takes a special pride in; (b) the person takes no special pride in, but which so orient her behavior that she would be at a loss about how to act and what to do 
without them; or (c) the person feels she could not change even if she wanted to. (p. 25)

So the identification features and the commitment choices we make need to be a matter of choice and choice we take pride in in order for them to constitute a normative framework that guides behavior. A receding hairline, to take an example, cannot be considered as part of a person's personal identity because this is by no means a voluntary decision. In other words, it is the deliberate choices we make that constitute our style - our manner of dress, speech, and our personal moral framework. More often that not, the choices are individualistic - they set us apart not only from other individuals but also from other traditional group affiliations.

More significant, and more relevant to the concerns of this paper, is the social, collective identity. This refers to the social categories in which people place themselves (or are placed in by others) that determine their group affiliation and ultimately define their outlook. Fearon (1999) identifies two distinguishing features of social categories. First, they delimit explicit or implicit rules of membership according to which members are identified or not with the group; and second, they are understood in terms of ideology and behavior that is expected of members in certain situations.

Traditional social categories people often attach to for collective identity include categories like family, friendship, lifestyle choices, nationality, professional identity, team spirit and shared interests, religious beliefs, ethnicity, and political affiliations (Marsh, Bradely, Love, Alexander, \& Norham, 2007). When people attach to these categories, their actions or behaviors are obligated to be line with those typical of members of the group. More relevant to this paper, however, is identification with the nation, or what is called National Belonging. More on this, and on Ansaruallah's behavior as a group, in the next section.

\subsection{National Belonging}

"The issue of belonging," argues Anthias, "emerges in relational terms: both in terms of the construction of we-ness - i.e., those who can stand as selves - and the construction of "otherness"-i.e., in the construction of those that cannot stand as selves" (2008, p. 8). This attachment gets activated when fear of exclusion is present. If we feel we are not getting recognized or valued in a particular group, we stretch the boundary and align ourselves with another. The issue of belonging is realized along different dimensions, discussed in the previous section, the most relevant of which here is the nation.

National belonging is commonly defined in terms of ethnic (cultural) ancestry and civic (political) commitment (e.g., Wakefield et al., 2011). The ethnic conception is more deterministic (where membership is acquired because un-chosen cultural considerations) while the civic conception is more inclusive (where membership is granted because of chosen criteria). Ethnically, to be Yemeni is to be born in Yemen to Yemeni parents, and to observe the traditions and culture of the land. From a civic perspective, however, national belonging is an act of choice and commitment. The remainder of this section examines the behavior of the Ansaruallah group from both perspectives in order to draw preliminary conclusions about the national belonging of the movement.

Members of the movement share with fellow Yemeni some characteristics such as historical locatedness, religious beliefs, appearance, values, behavioral and ethnic traits, and experience. They were born in Yemen to Yemeni parents. They are Muslims (though belonging to a different sect of Islam) who speak Arabic and are living within the national boundaries of the state. They observe similar social customs and traditions with regard to the family, marriage, honor, hospitality, and architecture, to name a few. In their appearance, they are also obviously ethnically Yemenis.

Members of the movement also started a political party in 1990, were represented in the parliament in 1993, occupied the ministerial offices of Awqaf (religious endowments) and Interior Affairs, and more recently participated in the National Dialog Conference. They seem to recognize the state and operate within its "democratic" framework. So one could argue that they demonstrate belonging to the nation in both ethnic and civic terms.

However, a number of behaviors by the followers of the movement point to a different direction. First, in March 2012 the movement launched a satellite TV channel, Almasirah, carried on the Egyptian satellite NileSat. The group felt that a medium that was needed to counter the inflammatory accusations and heavy propagandizing by the state media. It was like a resistance media platform. Second, the national school syllabus is conventionally designed by a national institution - the Ministry of Education. Refusing the national syllabus and using one of your own is also an act of resistance. There have been reports of school textbook used in Sa'ada schools that are different than those used in Yemeni schools outside the province.

Third, the group does not take pride in Yemen's national symbols. They neither play the national anthem nor stand for it in on formal occasions. They do not take pride in the national flag, either. Their cars and homes fly 
their own flag with its anti-American, anti-Jewish slogan, and in their rallies it is the only one they wave. Besides, the group carries out religious practices and hold religious festivals unobserved by fellow Yemenis. They commemorate Ghadeer and Ashoura, publically celebrate the birth of Prophet Muhammad, and build and visit shrine for their religious leaders. They celebrate these festivals in the manner of Twelver Shiite-a manner unseen before in Yemen, and these celebrations are attended by huge numbers of followers.

Fourth, the Ansaruallah slogan bears the tricolor of the Iranian flag. This banner starts with the phrase "God is Great", which figures twenty-two times on the fringes of the green and red bands of the Iranian flag. The group's rebranding themselves as Ansaruallah brings them closer, at least morphologically for now, to the Lebanon-based, Iran-supported "terrorist" group Hezbollah. In fact, Ansarullah's inception is similar to Hezbollah's. Like Hezbollah, it started as a religious movement conceived by Shiite Muslim clerics. The movement later grew into an organization with seats in the parliament and the government. It operates its own media outlets, has a military wing, and overseas an international border.

Last, and surely not least, the group has its own military uniform, organizes military funerals for its "martyred" leaders, and has medium and heavy military machinery that fended off the Yemeni military and Saudi Arabian military. Are we looking at a de facto state within the Yemeni state? And are Ansaruallah asserting an identity parallel to that associated with the state?

Examination of routinic behavior of the movement, therefore, does not give us conclusive evidence about the national belonging of the movement. The remainder of the paper examines the group's political rhetoric in search for answers to the questions raised by this paper.

\section{Objectives}

This paper attempts a transitivity analysis of Ansaruallah's proposals to the NDC in order to answer the following three questions.

1) In what terms is Ansarullah's social identity constructed?

2) How is the nation promoted as a value in Ansaruallah's political rhetoric?

3) How important is national belonging in Ansaruallah's construction of their social identity?

\section{Methodology}

\subsection{Data}

The corpus of Ansaruallah's political rhetoric is constituted by the political speeches of their successive leaders, the press releases and publications of their political council, and the statements of their current leader Abdulmalik Alhouthi reported by his media office. This corpus is partly available online in the group's website at www.ansaruallah.com.

Ansaruallah's proposals to the National Dialog Conference are one of the publications of their political council. The proposals have been published in 2013 in book form running into 280 pages covering four of the issues addressed by the NDC, namely, the Sa'ada Issue, the Southern Issue, State Building, and Good Governance. Of these four, the study samples the Sa'ada Issue, which constitutes more than one third of the publication. More importantly, the Sa'ada Issue is more directly relevant to the concerns of this paper, namely, the investigation of identity and national belonging in Ansaruallah's rhetoric. The Sa'ada Issue part of the book can also be retrieved from the NDC web page at http://www.ndc.ye/ar-issue.aspx?show=2.

\subsection{Theoretical Framework}

The theoretical framework of this study is informed by the transitivity model. The original version of the model was developed by Halliday $(1970 ; 1971)$, and the two decades that followed produced a number of modified versions of the same model (Berry, 1975; Halliday, 1985; Simpson, 1988; Simspon, 1993; Halliday, 1994).

Halliday (1975) identifies seven functions of language, one of which is the ideational function. He argues that language is a resource for making meaning and a means for representing the world. In Halliday's words,

It is through this function that the speaker or writer embodies in language his experience of the phenomena of the real world; and this includes his experience of the internal world of his own consciousness: his reactions, cognitions, and perceptions, and also his linguistic acts of speaking and understanding. (1971, pp. 332-333)

This ideational function of language is realized through the grammatical system of transitivity- the system of options made by the language user to codify their experience of a particular event or evaluation of a particular experience. Halliday posits that these options involve three elements: the processes, the participants and the circumstances. The processes are realized in the verbal phrase, the participants in the nominal phrase(s), and the 
circumstances in the adverbial and/or prepositional phrase(s). This is the basic skeleton of the transitivity model shared almost all later versions of the model, and which forms the central component of the analytical toolkit of the critical linguist. The differences are in the types of processes identified and the semantic roles assigned to the participants and adjuncts. This paper adopts Simpson's (1988) version of the transitivity model as the theoretical framework for the investigation of identity and national belonging in Ansaruallah's political rehtroic.

Simpson's transitivity framework draws extensively from Halliday's (1985) model, with some components of the model drawn from an earlier version proposed by Berry (1975). According to Simpson (1988), transitivity shows "how speakers encode in language their mental picture of reality and how they account for their experience of the world around them" (p. 167). Simpson argues that speakers encode their conceptualization of the world in the grammatical structure of the clause. The processes, the participants, and the circumstances all combine to reveal how a speaker labels people and categorizes the "goings-on" which constitute reality, i.e. whether they are presented in terms of doing, happening, feeling or being (Halliday, 1985, p. 101).

Simpson identifies five processes, two participant roles to each process, and leaves the category circumstances open (to be filled by temporal, spatial, causal, conditional and other adjuncts). The first process in the material process, or the process of doing, which is subdivided into event processes (where the actor is inanimate) and action processes (where the actor is animate). The latter further subdivides into intention processes (processes performed voluntarily) and supervention processes (processes that just happen). Associated with the material processes are two inherent participant roles, namely, Actor (which is obligatory) and Goal (which is optional).

The second set of processes is the mental processes, or the processes of sensing. Mental processes are subdivided into perception processes (processes of seeing, hearing, etc.), reaction processes (processes of liking, hating, etc.), and cognition processes (processes of thinking, recognizing, etc.). Associated with the mental processes are the two inherent participant roles of Sensor (the "feeler") and Phenomenon (that which is felt).

The third type of processes is the relational processes, or the processes of being. Relational processes express relationships between elements in the clause. These relationships may be intensive (relationships of equivalence), circumstantial (processes of circumstances), or possessive (processes of possession). Associated with relational processes are the two inherent participant roles of Carrier and Attribute.

The fourth group is the existential processes, or the processes that assert the existence of something. These processes typically include the word "there" as a dummy subject, and typically also have one participant role the Existent (that which exists).

The last process type is the behavioral processes, or the processes of physiological and psychological behavior. These processes include such behaviors as breathing, dreaming, and smiling. Associated with these processes are the key participant roles of Behaver (the conscious being involved in the process) and Behavior.

\subsection{Procedure}

This study raises three questions. The first relates to the way Ansaruallah encode their group identity. The second and third relate to the way the way the nation is promoted as a value and as a marker of belonging in Ansaruallah's political rhetoric.

In order to answer these questions, Ansarullah's proposals on the Sa'ada issue will be subjected to a transitivity analysis along the lines of the model proposed by Simpson (1988). All clausal constructions making textual reference to Ansaruallah, Yemen, Yemenis, national institutions, and the national government will be examined. These nominal groups will be analyzed to define the participant roles assigned to each nominal, and how these choices encode Ansaruallah's image of themselves and position Ansaruallah vis-à-vis the Yemeni state, the Yemeni people, and the Yemeni national institutions.

The clausal structures will also be examined for the types of processes used with each nominal group. The choice of processes reveals Ansaruallah's ideological evaluation of the state, state institutions and fellow Yemenis. They also indicate how Ansaruallah evaluate action by them and action on them. Analysis of all these choices will suggest how Ansaruallah conceptualize their collective identity and identify the parameters that define this conceptualization. It will also highlight the significance of the nation as a marker of belonging in the construction of Ansaruallah's group identity.

\section{Analysis}

\subsection{General Textual Features}

Ansaruallah's proposals to the NDC were published in book form running into two hundred and eighty pages and covering four major issues. Of these issues, the analysis singles out the first, and major issue in the book, the 
Sa'ada issue, which runs into one hundred and five pages, or ninety-three excluding the introduction. The number of paragraphs in the selected part is two hundred ninety nine and the number of sentences is a little above three hundred. So every page on average has about three paragraphs and almost every sentence is a paragraph long.

\subsection{Ansaruallah}

Ansaruallah are mentioned twenty-four times in the text, and they constantly appear in long sentences. Some of these sentences are almost three hundred words long, and the average sentence length where Ansrarullah are mentioned is 63 words long. The long sentences produce complex long NPs and multiple levels of textual subordination. It takes the reader a long time to work through the structure of the nominal in order to reach to the verbal element of the sentence, or the proposition, which is deeply embedded. Except on four occasions, Ansaruallah are always subordinated at lower levels of structure in the text. This allows for packaging as assumptions propositional content that would otherwise be open to debate or questioning. Packaged as an assumption in the text are the injustices Ansaruallah suffered by the state and its regional and international allies. These are passed on as given in eighteen structures ranging between sixteen to two hundred ninety three words long. Also assumed is their identification with Sa'ada in opposition to Yemen, and the popular support they enjoy inside Sa'ada and outside.

The twenty-four references to Ansaruallah break down add follows.

Table 1. References to Ansaruallah

\begin{tabular}{ll}
\hline Type of Process & Number \\
\hline Material Action Intentional & 13 \\
Material Action Event & 11 \\
\hline
\end{tabular}

As shown in the table, in all their twenty-four appearances Ansaruallah figure in Material Action structures. Whenever they appear, there is always action. Thirteen of these are Material Action Intentional structures - structures that involve action by human agents, and the other eleven are Material Action Event structures that involve action but non-human agents. Interestingly, and consistently, Ansaruallah assume the participant role of Goal in all these structures. In other words, Ansaruallah are the objects of all verbs in all structures involving them and they never assume the participant role of Agent or any other participant role. The action is always action on them, never by them. Ansaruallah construct themselves as goals or recipients of action, and this is the identity they create for themselves throughout the text.

\subsection{Yemen}

Yemen is referred to seventy-seven times in the text. It is referred twenty-five times by name "Yemen", twenty-five times in political terms "state", twenty times in geographical terms "land", and only eight times in nationalistic terms "homeland".

\subsubsection{Reference by Name}

Yemen is referred to by name twenty-four times in the text, as illustrated in the table below.

Table 2. References to Yemen by name

\begin{tabular}{llll}
\hline Type of Process & Number & Sub-type & Number \\
\hline Relational & 15 & Circumstantial & 11 \\
& & $\begin{array}{l}\text { Posessive } \\
\text { Intensive }\end{array}$ & 2 \\
Material Action Intentional & 9 & & 9 \\
\hline
\end{tabular}

As shown in the table, references to Yemen by name are limited to non-action refereces. In the 16 relational references, Yemen is a place where Islam flourished and is known for its cultural diversity. It is associated with Islamic schools is even described as Islami Yemen. It is also a subsidiary of the US administration, and the scene of human rights violation, wars and sectarian divisions with catastrophic results.

The other nine references to Yemen by name are in Material Action Intentional structures. Yemen continues to assume the participant role of Goal in all the structures. It is the target of US-Israel hegemony the US-Israel 
attempts tp control Yemen, corrpuption plagued by chronic corruption, and wars besieged by wars. The Yemeni regime is also Actor of action that has resulted in endangering Yemen's regional and international relations, animosity with friendly countries, and losing strategic relations with other countries.

\subsubsection{Yemen: The State}

In the twenty-five references to it as a "state", Yemen is not constructed in positive terms. In fourteen of these references, it is constructed as a failed state. Its resources are mismanaged, its treasurey has been drained, and its dignity has been undermined. The state has confiscated freedon of thought, its rulers are a gang of thieves, and it is devoid of all that is associated with states. In all these sentences, Yemen figures in Material Action Intentional structures, and consistently assumes the participant role of Goal. For Ansaruallah, the state has always been abused, and the agent is always Saleh's neopatrimonial autocracy.

In six other references, Yemen is a non-state, and Yemenis have lost confidence in it. In these references too, the state is Goal of action initiated by Saleh's regime and his circles of influence. The state has been turned into décor, a police state, and a non-state. The state project has been corroded and confiscated, and needs re-building and rehabilitation.

In addition to the negative construction of the state on twenty occasions, there is non-negative (but not categorically positive) construal in five places. These are structures where Ansaruallah or Sa'ada are Goal of benefits or privileges whose Agent is the state. These are looked-for, not already attained, benefits. Ansaruallah insist that they should get accommodated in state agencies, compensated with jobs, and represented in state institutions. So the only context Ansaruallah would frame Yemen positively, or non-negatively, is when they are participating in running the state and sharing its resources.

4.3.3 Yemen: The Land

In twenty other references, Yemen is referred to as a "land", as illustrated in the table below.

Table 3. References to Yemen as land

\begin{tabular}{llll}
\hline Type of Process & Number & Sub-type & Number \\
\hline Relational & 11 & Circumstantial & 7 \\
& & Posessive & 4 \\
Material Action Intentional & 9 & & \\
\hline
\end{tabular}

The Relational Processes of Possession are all in the context of economic resources being seized by the regime seizing resources of the land, and the circumstantial processes are all process of location intellectual and sectarian diversity in the land. Yemen is a "place" where intellectual diversity is not respected, influential powers are mediating, conflicts are taking place, sectarian division is encouraged, and where unfair representation of all parties flourishes but must be criminalized. All these are depersonalized references, lacking in emotional attachment.

In the other nine references, Yemen appears in Material Action Intentional structures. In all nine appearances, it framed as the Goal of all the action. The Agent, consistently Saleh's autocratic regime, is managing the land, administering the land, opening the land to Americans, stigmatizing the land by poverty, and plaguing the land with corruption. The only one reference where Ansaruallah attach their name to the "land" is on page 100, and here Ansaruallah are also the Goal in Material Action Intentional processes of targeting and conspiracy by circle of power in Saleh's regime drag Ansaruallh into conflicts in the land.

4.3.4 Yemen: The Homeland

There are also seven references to the homeland, as illustrated in the table below.

Table 4. References to Yemen as homeland

\begin{tabular}{ll}
\hline Type of Process & Number \\
\hline Relational Processes of possession & 2 \\
Material Action Intentional & 5 \\
\hline
\end{tabular}

In the Relational processes, it is Sa'ada's interests that are threatened by the state and its allied international powers autocratic regime siding with international powers at the expense of the interests of the homeland, and 
the 519 detained and forcibly missing Ansaruallah militants are framed as co-national of the homeland 519 detained \& forcibly hidden members of this homeland.

In the five Material Action structures, on the other hand, the Goal is consistently the homeland, and the identity of the Agent reveals the identity of the homeland. In these processes, the state aggression against Ansaruallah is framed as aggression against the homeland, the wars by the Yemeni regime is an error against the homeland, and the Saudi military intervention constitutes a violation of the sovereignty of the homeland. Given that the Yemeni state launched the war against Ansaruallah in Sa'ada and that the regional (Saudi Arabia) and international powers sided with the Yemeni state, it becomes obvious that Sa'ada, in opposition to Yemen, is construed as the homeland and Ansaruallah militants are the national of the homeland.

\subsection{Yemeni People}

The Yemeni people are referred to sixty-three times in the text. They are called the Yemeni people on twenty-two occasions and referred to as the co-nationals forty-one times, as illustrated in Table 5 below.

Table 5. References to Yemeni people

\begin{tabular}{lll}
\hline & Type of Process & Number \\
\hline Yemeni people (22) & Material Action & 18 \\
& Relational & 2 \\
& Behavioral & 2 \\
co-nationals (41) & Material Action & 36 \\
& Relational & 5 \\
\hline
\end{tabular}

In the eighteen references, the Yemeni people assume the participant role of Goal (eight times), Agent (five times), and Circumstantial (five times). When they are the Goal, they are acted upon by the US embassy US embassy instructed the Yemeni people to support the regime, the Yemeni regime regime imposed an laien ideology on the Yemnei people, the Saudi military the Saudi military intervention constituted aggression against the Yemeni people, and the Yemeni political parties parties traded blood of the Yemeni people for material gains. When they are Actor, they retaliate against the authoritarian practices of the Yemeni regime the Yemeni people revolted against the neopatrimonial autocracy, and fight to exercise their rights and to build a new Yemen the Yemeni people took to the streets to topple this regim. In their circumstantial roles, the Yemeni people are lied to and denied information regime denied media access to conceal truth from the people. In the other four appearances, the Yemeni people are projected as having concerns not addressed responsibly by the state the regime did not deal with concerns of the people and lacking conviction in the authority of the ruling regime the Yemeni people distrust the ruling authority. They have little trust for the regime, and the only issue that unites them is the Sa'ada issue.

The other forty-one references, however, offer a different construction. Generally, a sense of belonging to a nation strengthens when an external threat becomes clear, causing individuals to seek to unite with fellow nationals for mutual protection against the common threat. And this is what happens throughout the text. Apart from five relational processes, all other 36 references construct the "co-nationals" in Material Action Intentional structures. In these appearances, no exception, the co-nationals are Goal of intentional action. They have been detained and tortured by the Sana'a regime, evacuated from their homes, forcibly displaced, and burned alive. They have been victims of six unjustified wars, continuous aggression, and massacres, causing them immense material and psychological damage. The Actor of these MAI structures is consistently the "Yemeni" ruling authority, also referred to as the Sana'a Regime The protection Ansaruallah get is from the group, the privileges they get are from the group, and their loyalty is to the group, not to the state, and their identity is associated with the group, not with the country. In the text, the homeland, mentioned five times, is always Sa'ada, not Yemen, and the co-nationals, mentioned forty-one times, are always Ansaruallah militants or Sa'ada residents. Ansaruallah retreat into a sub-identity that defines them in opposition to the national identity represented by their oppressors.

\section{Conclusions}

Analysis of Ansaruallah's proposals to the NDC provides answers to our research questions. In all twenty-four textual references to them, Ansaruallah are consistently framed as the goal of action by the Yemeni military "machines". They are textually constructed as an oppressed group whose members are bound by religion and oppression. They are underrepresented, targeted, and living in underdeveloped Sa'ada, and this textually created 
identity is borne by the analysis of the transitivity patterns in the text. In this frame, the common threat to Ansaruallah's existence is the Yemeni government (an ally of the United States), and the threatened identity is their Shiite identity. This makes Ansaruallah retreat into their religious, oppressed sub-identity.

In consistence with this projection of the Yemeni government, Ansaruallah distanced themselves from Yemen and fellow Yemenis. Nowhere in the proposals do Ansaruallah identify themselves with Yemen. None of the references to Yemen, for example, is suffixed with a possessive marker, which is common use in Arabic to suggest belonging. These references are depersonalized, lacking in emotional attachment. And like with the references to Yemen, references to Yemeni people are detached, reflecting an outsider perspective. The text refers to the Yemeni people in the exclusive third person, rather than in the inclusive first person, and the reporting voice is more a neutral than an involved participant. There is little sense of attachment to the country and to the people of Yemen.

In line with the detachment from Yemen and fellow Yemenis, Ansaruallah adopt an outsider perspective with respect to the national institutions. The national government and national institutions are projected as detached and unexpressive of Ansaruallah's concerns. The Yemeni government is constructed as an authority of war, a gang, and a tool of American aggression. The Yemeni national military is a military machine made up of corrupt, secretive security apparatus. The text makes references to the ruling authority in Sana'a, the Yemeni regime, and the Yemeni radio (and there is no radio by that name of course). They also reject to associate with Yemeni institutions. The Yemeni president is a head of state, the government is a ruling authority and the national military is an armed militia of mercenaries.

In contrast, Ansaruallah expressed emotional attachment to Sa'ada and solidarity with Ansaruallah militants. The five references to homeland in the text all define Sa'ada as the homeland that is attacked by the Yemeni and Saudi military machines, and about ninety percent of the references to the co-national identify either Ansaruallah militants or Sa'ada residents as the referents.

\section{References}

Anouti, H. (2011). The Houthi insurrection in Yemen: Shedding light on the problem of minorities in the Middle East (Master's Thesis). Lebanese American University, Beirut.

Anthias, F. (2008). Thinking through the lens of translocational positionality: An intersectionality frame for understanding identity and belonging. Translocations, 4(1), 5-20.

Berry, M. (1975). Introduction to systemic linguistics: Structures and systems (Vol. 1). London: Batsford.

Boucek, C. (2010). War in Saada: From local insurrection to national challenge (p. 110). Retrieved from http://carnegieendowment.org/files/war_in_saada.pdf

Crisis Group Middle East. (2014). The Huthis: From Saada to Sanaa (p. 154). Retrieved from https://www.crisisgroup.org/middle-east-north-africa/gulf-and-arabian-peninsula/yemen/huthis-saada-sanaa

Deng, F. M. (1995). War of visions: Conflict of identities in the Sudan. Washington, DC: Brookings.

Fearon, J. D. (1999). What is identity (as we now use the word)?. Unpublished manuscript. Retrieved from http://dev.wcfia.harvard.edu/sites/default/files/initiative_identity_fearon2.pdf

Halliday, M. (1970). Language structure and language function. In J. Lyons (Ed.), New horizons in linguistics (pp. 140-165). Harmondsworth: Penguin.

Halliday, M. (1971). Linguistic function and literary style: An inquiry into the language of William Golding's The Inheritors. In S. Chatman (Ed.), Literary style: A symposium (pp. 330-360). London: Oxford University Press.

Halliday, M. (1985). An introduction to functional grammar (1st ed.). London: Edward Arnold.

Halliday, M. (1994). An introduction to functional grammar (2nd ed.). London: Edward Arnold.

Hodge, R., \& Kress, G. (1993). Language as ideology. London: Routledge.

Hogg, M. A., \& Abrams, D. (1988). Social identifications: A social psychology of intergroup relations and group processes. London: Routledge.

Islamopedia Online. (2012). The Houthis. Islamopedia Online. Retrieved from http://www.islamopediaonline.org/country-profile/yemen/political-landscape/houthis

Jenkins, R. (1996). Social identity. London: Routledge. https://doi.org/10.4324/9780203292990

Lux, A. (2009). Yemen's Last Zaydi Imam: The Shabab al-Mu'min, the Malazim, and Hizb Allah in the thought of 
Husayn Badr al-Din al-Huthi. Contemporary Arab Affairs, 2(3). https://doi.org/10.1080/17550910903106084

Marsh, P., Bradley, S., Love, C., Alexander, P., \& Norham, P. (2007). Belonging. Oxford: The Social Issues Research Center. Retrieved from http://www.sirc.org/publik/Belonging.pdf

Salmoni, B. A., Loidolt, B., \& Wells, M. (2010). Regime and periphery in northern Yemen: The Huthi phenomenon. Rand Corporation.

Simpson, P. (1988). The transitivity model. Critical Studies in Mass Communication, 5(2), $166-172$. https://doi.org/10.1080/15295038809366696

Simpson, P. (1993). Language, ideology and point of view. London: Routledge. https://doi.org/10.4324/9780203312612

Thiel, T. (2012). After the Arab Spring: Power shift in the Middle East?: Yemen's Arab Spring: From youth revolution to fragile political transition. Retrieved from https://www.lse.ac.uk/IDEAS/publications/reports/pdf/SR011/FINAL_LSE_IDEAS_YemensArabSpring_ Thiel.pdf

Wakefield, J. R., Hopkins, N., Cockburn, C., Shek, K. M., Muirhead, A., Reicher, S., \& van Rijswijk, W. (2011). The impact of adopting ethnic or civic conceptions of national belonging for others' treatment. Personality and Social Psychology Bulletin, 37(12), 1599-1610. Retrieved from https://www.researchgate.net/profile/Juliet_Wakefield/publication/51544664_The_Impact_of_Adopting_Et hnic_or_Civic_Conceptions_of_National_Belonging_for_Others'_Treatment/links/0deec520146238f5ed00 0000.pdf

Winter, L. (2013). The Asnar of Yemen: The Houthis and al-Qaeda. Small War Journal. Retrieved from http://smallwarsjournal.com/jrnl/art/the-ansar-of-yemen-the-huthis-and-al-qaeda

\section{Copyrights}

Copyright for this article is retained by the author(s), with first publication rights granted to the journal.

This is an open-access article distributed under the terms and conditions of the Creative Commons Attribution license (http://creativecommons.org/licenses/by/4.0/). 